\title{
Zur Statistik
}

über die

\section{Verbreitung des elektrischen Lichtes \\ im}

\section{Versorgungsgebiet deutscher Gasanstalten}

und einiger Städte des Auslandes

\section{4}

gesammelt im Auftrage des Vorstandes

des

Deutschen Vereins von Gas- und Wasserfachmännern

von

FI. Bunte, Generalsecretär,

bearbeitet in Verbindung mit

Dr. Rasch,

Privatdocent an der technischen Hochschule Karlsruhe. 
